\title{
Assessment of noise and ozone levels in a small industrial urban area
}

\author{
Evaluación de los niveles de ruido y ozono en una zona industrial urbana
}

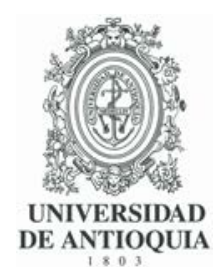

\author{
Leonardo Furst (iD) ${ }^{1}$, Manuel Feliciano (iD) ${ }^{2 *}$, Artur Gonçalves (iD) ${ }^{2}$, Felipe Romero (D) ${ }^{3}$ \\ ${ }^{1}$ Instituto Politécnico de Bragança, Campus de Santa Apolónia. 5300-253 Bragança. P. C. 5301. Bragança, Portugal. \\ 2 Centro de Investigação de Montanha (CIMO), Instituto Politécnico de Bragança, Campus de Santa Apolónia. 5300-253 \\ Bragança. P. C. 5301. Bragança, Portugal. \\ ${ }^{3}$ Instituto de la Construcción de Castilla y León (ICCL). Villadiego, Edificio Politecnica. C. P. 09001. Burgos, España.
}

\section{CITE THIS ARTICLE AS:}

L. Furst, M. Feliciano, A. Gonçalves and F. Romero.

"Assessment of noise and ozone levels in a small industrial urban area", Revista

Facultad de Ingeniería Universidad de Antioquia, no. 105, pp. 76-88, Oct-Dec 2022. [Online]. Available: https: //www.doi.org/10.17533/ udea.redin. 20210960

\section{ARTICLE INFO:}

Received: December 05, 2019 Accepted: September 18, 2021 Available online: September 20, 2021

\section{KEYWORDS:}

Noise pollution; industrial areas; environmental monitoring; ozone

Contaminación sonora; zona industrial; vigilancia ambiental; ozono
ABSTRACT: Monitoring environmental parameters in urban centers has become a critical step for health risk assessment. In this study, conducted in the industrial park of Mirandela (Portugal), an environmental monitoring system consisting of a meteorological station, a class 1 smart sound sensor and three reference optical gas analyzers were deployed to measure noise levels, tropospheric ozone concentrations, carbon monoxide, and nitrogen oxides, during winter and spring of 2019. The interdependence among all variables was evaluated, and legal compliance was assessed according to the European Union (EU) target values for ozone. Higher concentrations of nitrogen oxides and carbon monoxide were observed during rush hours, while ozone concentrations increased as a consequence of the emissions of primary pollutants after sunrise reaching their maximum values at about 13:00 to 14:00h. Regarding the Accumulated Ozone Exposure (AOT), both target values set by the EU for AOT40 vegetation and forest have been exceeded. For A0T60, the observed values were below target; however, the threshold for NET60 was exceeded even before the end of 2019. Noise levels were higher during rush hours, because of higher traffic intensity; however, noise level indicators (Lden, Ln) remained within the legal limits. It was possible to realize that urban traffic is the most relevant source of noise and local air pollution. These results can be used to define strategies that may improve the environmental performance of the studied industrial park.

RESUMEN: La vigilancia de los parámetros medioambientales es una acción importante para la evaluación de riesgos para la salud en los centros urbanos. En este estudio, realizado en el parque industrial de Mirandela (Portugal), se implementó un sistema de monitoreo medioambiental compuesto por una estación meteorológica, un sonómetro de clase 1 y tres analizadores ópticos de gases, para monitorizar los niveles de ruido, las concentraciones de ozono, monóxido de carbono, y óxidos de nitrógeno durante la primavera y invierno de 2019. Se evaluó la interdependencia entre las variables y el cumplimiento legal con los valores objetivo para el ozono establecidos por la Unión Europea (UE). Se observaron concentraciones más altas de óxidos de nitrógeno y monóxido de carbono durante las horas de punta, mientras que las concentraciones de ozono aumentaron por las emisiones de contaminantes primarios, alcanzando valores máximos aproximadamente de las 13:00 a 14:00h. Cuanto a la Exposición Acomumulada a Ozono (AOT), se han excedido los valores objetivos para AOT40. Mientras que para A0T60, el valor observado estaba abajo del objetivo, sin embargo, se ha excedido el indicador NET60. Los niveles de ruido fuéron mayores en las horas de punta, relacionados con la mayor intensidad de tráfico, pero los indicadores de ruido (Lden, Ln) permanecieron dentro de los límites legales. Los resultados obtenidos pueden ser utilizados para centrar los esfuerzos en la mejora de la calidad medioambiental del parque industrial.

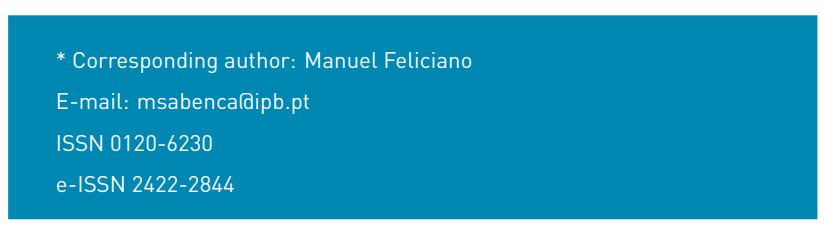




\section{Introduction}

The rapid urban expansion, associated with intense population growth rates over the last centuries, tends to influence and modify various environmental aspects, generating impacts on the air, water, soil, and biodiversity [1-4]. Under such circumstances, it is clear that the increase in urban traffic, expansion of industrial zones, and suppression of vegetation are the main degradation factors of urban air quality and local climate changes [5-7]. In addition, a large part of the population is exposed to different levels of environmental noises, capable of producing diverse effects on human health and well-being [8]. Therefore, air pollution and environmental noise are considered the two major environmental pressures associated with decreased quality of life in cities [9].

Several studies emphasize the adverse effects of these components on human health [9-11], including respiratory and heart diseases [12-14], and causing annoyance and decreasing the cognitive ability [15], [16]. Thus, one of the great challenges for contemporary cities managers is providing quality of life to their inhabitants by improving the urban environment. To achieve this purpose, noise levels and air quality monitoring are extremely important to assess environmental risks, as well as to maintain or improve the environmental quality in urban centers and on the outskirts [15], [17].

The main aim of this study was to study ozone, carbon monoxide, nitrogen oxides, and noise levels in the industrial park of Mirandela (Portugal). Since ozone is a very unstable secondary pollutant, its presence in the troposphere is mainly due to its photochemical production, which takes place through the oxidation of hydrocarbons and carbon monoxide in the presence of nitric oxides and solar radiation [18]. For this reason, nitric oxides, carbon monoxide, along with meteorological parameters were also monitored in this research.

To achieve the objectives of this study, a monitoring system composed of one weather station, three gas analyzers and, one noise sensor was installed in the Mirandela industrial park. The data collected during the winter and spring months of 2019 was used to correlate the different variables monitored with ozone production. This monitoring system allowed further monitoring of the daily noise levels and the identification of the weekly noise profile. Additionally, for 2019, the analysis for AOTx (Accumulated Ozone Exposure above a Threshold of $x \mathrm{ppb}$ ) and NET 60 was carried out. Over the next sections of this paper, a brief characterization of the industrial park, the methodological details of the study and the main air quality, and noise results are presented and discussed.

\section{Understanding noise and ozone pollution}

Air pollution is defined as a condition where one or more substances are present in the atmosphere at concentrations above normal ambient levels and particularly during a sufficiently long period to produce adverse effects on the health of humans, animals, and plants, or to cause material damage $[19,20]$. According to the European Directive, noise corresponds to any unwanted sound or set of sounds that cause annoyance or may have an impact on human health, emitted by human activities, such as road traffic, rail traffic, air traffic, and industrial sites [21].

Both air and noise pollution are composed of three elements: source, transport (path), and receptor [22]. In an industrial park, the sources of noise and air pollution are stationary or mobile, relative to the buildings and transportation systems, respectively. The receptor is any biotic or abiotic organism that suffers the adverse effects of air pollution, including humans, animals, plants, water, and soil [22]. In living organisms, the effects range from minor allergies to severe chronic illness [9, 23]. The third and last element, transport, corresponds to the path or mechanisms that move the pollutant or sound from the source to the receptor $[22,24]$. Along the way, an air pollutant can change several times, reacting in the atmosphere producing another pollutant or being deposited by turbulent flow, rain, or snow [25]. For sound, the path mainly affects the propagation distance due to the existing obstacles [26].

To better understand the dynamics of ozone, it is necessary to know the mechanisms of its formation. Figure 1 shows the simplified ozone formation cycle with its main reactions. The reactions between $\mathrm{O}_{3}, \mathrm{NO}$, and $\mathrm{NO}_{2}$ (R1-R3) are part of a well-established null cycle [18]. Thus, during daylight hours, theoretically, $\mathrm{NO}, \mathrm{NO}_{2}$ and $\mathrm{O}_{3}$ are typically balanced on a condition referred to a photostationary state [27]. An atmosphere only with nitrogen oxides does not favor the ozone production, as ozone can be recycled during the reactions. However, in the presence of other precursor gases such as carbon monoxide (R4-R5), and volatile organic compounds (R6-R9), new reactions are triggered, resulting in excess of ozone production $[28,29]$. These reactions lead to the formation of the hydroxyl $(\mathrm{OH})$, hydroperoxyl $\left(\mathrm{HO}_{2}\right)$ and organo-peroxyl $\left(\mathrm{RO}_{2}\right)$ radicals, which results in the formation of nitrogen dioxide without ozone consumption and, consequently, leading to higher ozone production rates. 


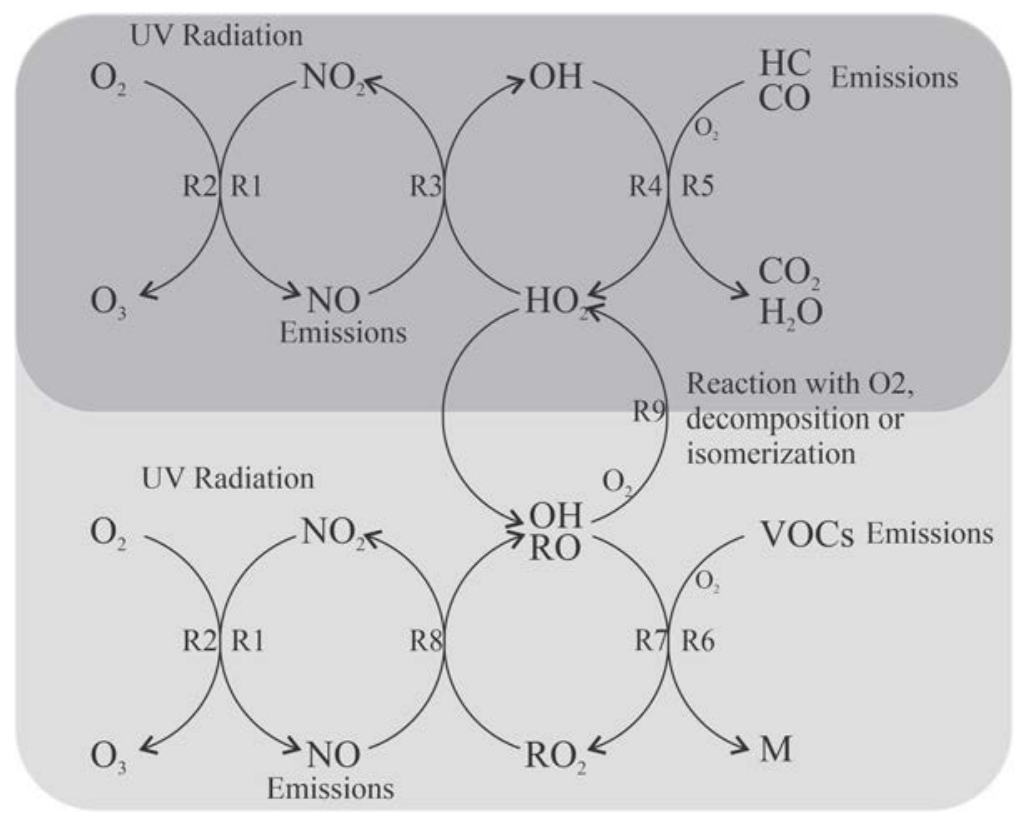

Photochemical formation of ozone in the presence of hydrocarbons, $\mathrm{CO}$ and $\mathrm{NOx}$

$\begin{array}{ll}\text { R1 } & \mathrm{NO}_{2}+\mathrm{hv} \rightarrow \mathrm{NO}+\mathrm{O} \\ \text { R2 } & \mathrm{O}+\mathrm{O}_{2}+\mathrm{M} \rightarrow \mathrm{O}_{3}+\mathrm{M} \\ \text { R3 } & \mathrm{HO}_{2}+\mathrm{NO} \rightarrow \mathrm{OH}+\mathrm{NO}_{2} \\ \text { R4 } & \mathrm{CO}+\mathrm{OH} \rightarrow \mathrm{H}+\mathrm{CO}_{2} \\ \text { R5 } & \mathrm{H}+\mathrm{O}_{2}+\mathrm{M} \rightarrow \mathrm{HO}_{2}+\mathrm{M}\end{array}$

Photochemical formation of ozone in the presence of VOCs and NOx

$\begin{array}{ll}\text { R6 } & \mathrm{CH}_{4}+\mathrm{OH} \rightarrow \mathrm{CH}_{3}+\mathrm{H}_{2} \mathrm{O} \\ \text { R7 } & \mathrm{CH}_{4}+\mathrm{O}_{2}+\mathrm{M} \rightarrow \mathrm{CH}_{3} \mathrm{O}_{2}+\mathrm{M} \\ \text { R8 } & \mathrm{CH}_{3} \mathrm{O}_{2}+\mathrm{NO} \rightarrow \mathrm{CH}_{3} \mathrm{O}+\mathrm{NO}_{2} \\ \text { R9 } & \mathrm{CH}_{3} \mathrm{O}+\mathrm{O}_{2} \rightarrow \mathrm{HCHO}+\mathrm{HO}_{2}\end{array}$

Figure 1 Ozone production cycle in the troposphere through photochemical reactions. Adapted [18, 29]

\section{Methodology}

\subsection{Industrial park of Mirandela - brief description}

This study was carried out in the urban industrial park of Mirandela $\left(41^{\circ} 29^{\prime} \mathrm{N} / 7^{\circ} 9^{\prime} \mathrm{W}\right)$, located in the northeastern region of Portugal, in the region known as Trás-os-Montes. The Industrial Park has an area of 33 hectares, with 97 lots distributed to different industrial and commercial sectors. It comprises approximately 65 companies of different typologies such as sausage and granite factories, oil mills, carpentry, locksmiths, and car repair shops. The Industrial Park is mostly surrounded by rural areas with olive trees plantations and open grassy spaces and is bounded by roadways to the west and south. Due to the wide variety of services, the industrial park has a relatively high car traffic intensity. The Mirandela downtown is located southwest of the Industrial Park. Mirandela is classified according to Köppen-Geiger climate classification system as Csa, defined as Mediterranean climate with dry and hot summer.

\subsection{Monitoring and analysis methods}

The air quality monitoring started in December 2018, with hourly measurements of carbon monoxide $[C O]$, nitrogen oxides $\left(\mathrm{NO}, \mathrm{NO}_{2}, \mathrm{NO}_{\mathrm{X}}\right)$, and ozone $\left(\mathrm{O}_{3}\right)$, covering for this study the period between December 1 , 2018, and October 1, 2019. All these gaseous pollutants were monitored according to the reference methods described by the Directive 2008/50/EC, using three gas analyzers: one ozone analyzer HORIBA APOA-370 (non-dispersive ultra-violet-absorption), one nitrogen oxides analyzer HORIBA APNA-370 (chemiluminescence) and one carbon monoxide analyzer HORIBA APMA-370 (non-dispersive infrared absorption). Noise monitoring started on February 8, 2019, using the CESVA TA120 noise sensor, with measurements taken every minute, covering the spring season of 2019. The noise sensor has class 1 accuracy according to IEC 61672-1 and was deployed outdoors as it has a weather protection cover. In addition, a meteorological station was used to characterize the prevailing local weather conditions, measuring the direction and wind speed, solar radiation, temperature, relative humidity, and precipitation. The gas analyzers, weather station, and noise sensor (Figure 2) have the capacity to send data remotely via GPRS system, enabling the data to be accessed through a remote server.

Based on the solar radiation data, the days were divided into daytime (8:00-19:00) and nighttime (20:00-7:00) to determine the correlation coefficient between the variables and the local and regional contribution to the prevailing $\mathrm{O}_{3}$ levels. These separate timeframes were chosen considering the ozone formation and depletion mechanisms that have a strong dependence on solar radiation.

For ozone, critical levels analyses were also performed - AOT40, AOT60, and NET60. The AOT40 (Accumulated Ozone Exposure above a Threshold of $40 \mathrm{ppb}$ or $80 \mu \mathrm{g} / \mathrm{m}^{3}$ ) was established by the United Nations Economic Commission for Europe under the Convention on Long Range Transboundary Air Pollution (UNECE-CLRTAP). By definition, AOT40 is the sum of the differences between 
the hourly ozone concentrations and $40 \mathrm{ppb}$ when the concentration exceeds $40 \mathrm{ppb}$ during daylight hours over the period of May-July for vegetation and April-September for forest, and represents the limit above which direct effects on vegetation occur [30]. For AOT40 vegetation, the European Union has a target value of $9000 \mathrm{ppb}$.h and a long-term target of 3000 ppb.h [30], while for the forest, the reference value is $10000 \mathrm{ppb} h$ [31] with a critical value of $5000 \mathrm{ppb}$ h [32]. These target values are averaged over 5 years. However, for the purposes of this study, the analysis for 2019 was carried out to verify the current situation within the established limits.

For human health protection, there is the AOT60 (Accumulated Ozone Exposure above a Threshold of 60 ppb or $120 \mu \mathrm{g} / \mathrm{m}^{3}$ ), calculated by summing the difference between the maximum 8-hour concentrations above 60 ppb and $60 \mathrm{ppb}$ with a ceiling of $2900 \mathrm{ppb}$.h throughout the year $[30,33,34]$. In conjunction with the AOT60 is NET60 (Number of Exceptions above a Threshold of $60 \mathrm{ppb}$ ), which sets a limit of 25 days in the year laveraged over 3 years), where maximum 8-hour ozone concentrations can exceed $60 \mathrm{ppb}$. In the long term, the European Union aims to reach 0 days, which would consequently bring the AOT60 to zero [30, 33].

Concerning noise, daily and weekly profiles were evaluated based on hourly average data observed during the spring months. Additionally, the noise assessment was based on the Portuguese General Noise Regulation (RGR) (Decree-Law No. 9/2007 of January 17) [35]. The RGR does not set noise limits to industrial parks themselves, but any activity located in an industrial park has to comply with criteria established in RGR for sensitive receivers (i.e., spaces where people live or stay) near industrial areas. The criteria set for those receivers depend on the classification established in the municipal master plan for the area where they are located. These areas can be classified into sensitive and mixed zones. The RGR [35] defines sensitive zones as areas for residential use, schools, hospitals or similar, and recreational or leisure spaces, and may also contain small shops and services since they do not operate at night, while mixed zones in addition to the uses for sensitive zones may contain shops, services, and industries working all day.

In the master plan of Mirandela, the residential areas near the industrial park are classified as mixed zones. For these areas, the RGR specifies the limit value of $55 \mathrm{dBA}$ for the night noise indicator (Ln) and a $65 \mathrm{dBA}$ for the day-evening-night noise indicator (Lden). Based on this, for research purposes, the monitoring point was evaluated as a mixed zone.

\section{Results and discussion}

\subsection{Daily profile of meteorological parameters, ozone and its precursors}

Figure 3 shows the diurnal profile of solar radiation, air temperature, relative humidity, and concentrations of ozone and its precursors.

The higher concentrations of the primary pollutants $1 \mathrm{CO}$ and $N O_{X}$ J registered between 8:00 and 10:00 and between 17:00 and 18:00, coincides with the greatest intensity of traffic associated with the beginning and end of the daily activities inside and outside the industrial park. The higher levels of these primary pollutants in winter show clearly the influence of other combustion sources, such as domestic combustion for heating water and ambient air in dwellings.

In winter, ozone concentrations increase from 8:00 until they reach a peak of $33 \mathrm{ppb}$ at 16:00. It is also noted that during rush hour (about 18:00), the increase in $\mathrm{NO}$ and $\mathrm{NO}_{2}$ concentrations did not imply a significant increase in ozone concentration, partially explained by the prevailing low solar radiation. The ozone pattern in spring and winter was similar; however as the days are longer and the incidence of solar radiation is higher, there are favorable conditions for ozone production. In spring, ozone concentrations rise from 7:00 to reach their peak at 14:00, remaining stable until 19:00. Considering also that $\mathrm{O}_{3}$ production depends on the concentration of $\mathrm{NO}, \mathrm{NO}_{2}$, $C O$, and volatile organic compounds, these gases are consumed as the $\mathrm{O}_{3}$ concentration increases. Because of the photostationary state, it is possible to observe in winter an ozone concentration near $30 \mathrm{ppb}$ between 14:00 and $17: 00$ and in spring a concentration near 50 ppb between 13:00 and 19:00.

\subsection{Relation between air quality and meteorological variables}

Tables 1 and 2 show the daytime and nighttime correlation coefficients between hourly means of individual pollutants ( $\mathrm{CO}, \mathrm{NO}, \mathrm{NO}_{2}, \mathrm{NO}_{\mathrm{X}}$ and $\mathrm{O}_{3}$ ) and the meteorological parameters for winter and spring. The values in bold were those that show a significant correlation at the 0.05 level (2-tailed). Similar to another study [36], a positive correlation was found between nitrogen oxides and carbon monoxide during daylight, indicating that both gases have the same source, mainly related to combustion processes (e.g., motor vehicles and industries).

Ozone showed a significant positive correlation with solar radiation and temperature during the daylight hours. This relation reverses during the night, due to the 

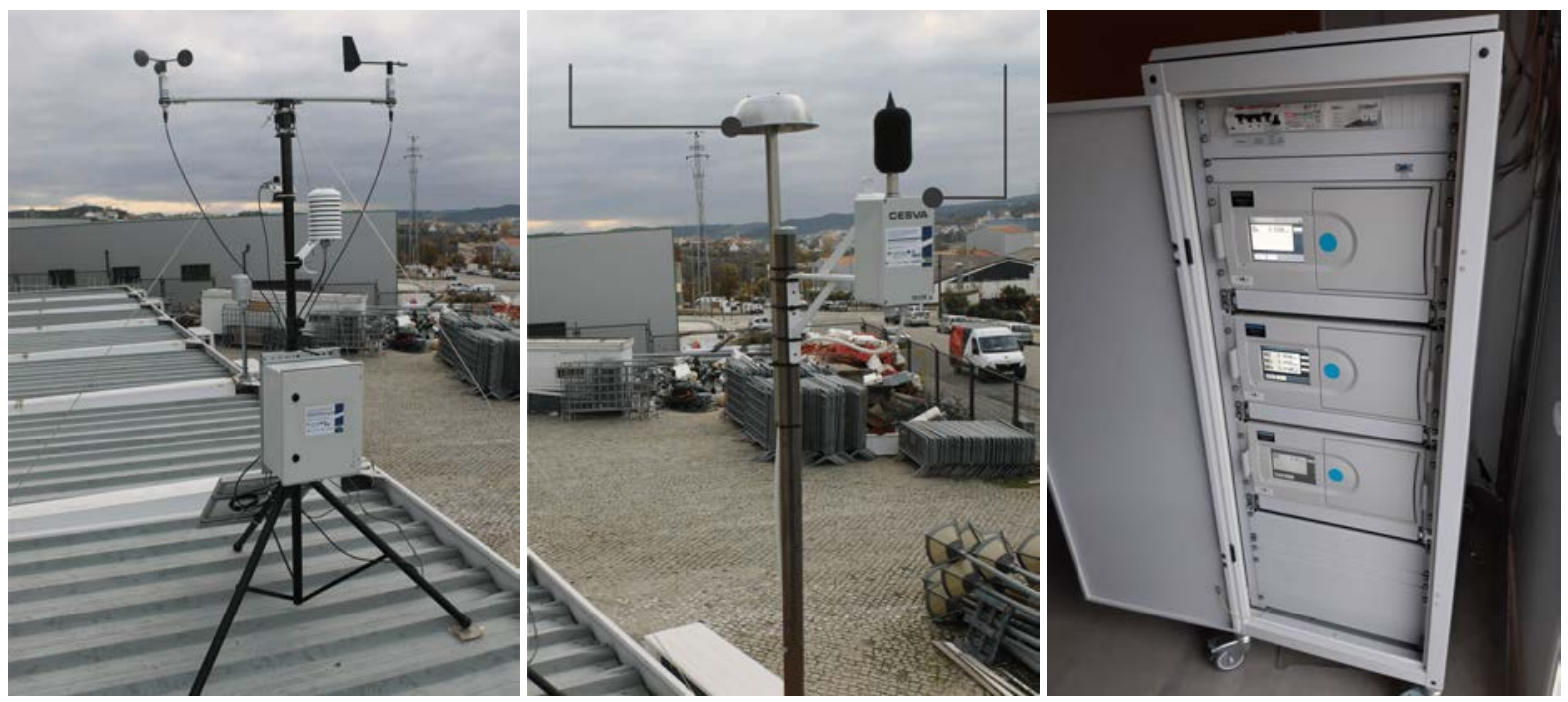

Figure 2 Set of the monitoring equipment used in the study: (A) Weather station; (B) air intake; (C) smart noise sensor; (D) gas analyzers container

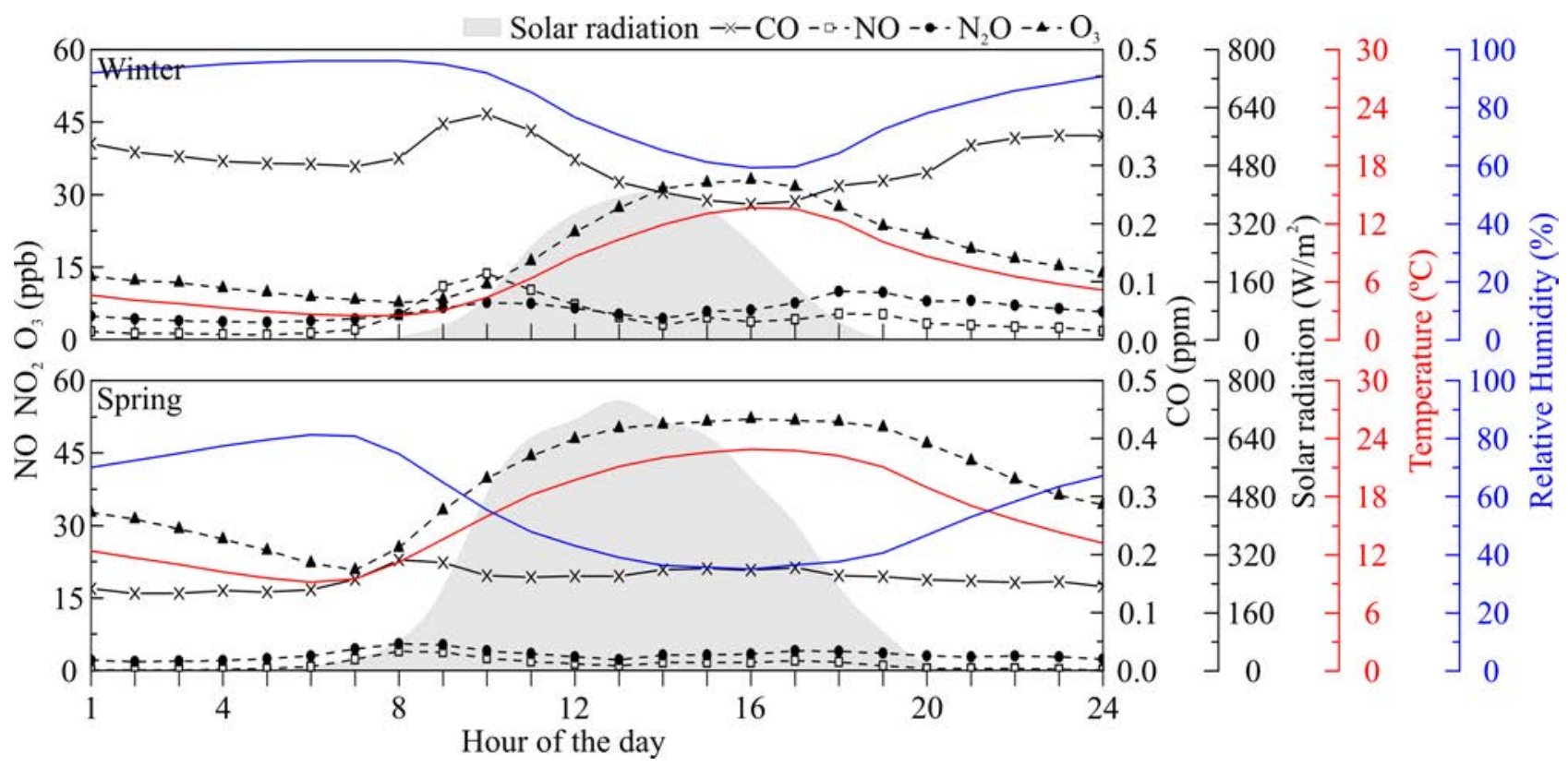

Figure 3 Average hourly variation of $\mathrm{NO}_{2}, \mathrm{NO}, \mathrm{CO}, \mathrm{O}_{3}$, solar radiation, temperature, and relative humidity during winter (top) and spring (bottom)

lack of solar radiation for ozone synthesis. This trend is observed in other studies [37, 38], showing that a favorable temperature and high solar radiation increase the photochemical reactions that generate ozone [39]. Moreover, based on reactions 1 to 3 , an inverse relationship between ozone and nitrogen oxides is also observed, which can be confirmed by the negative correlation between these gases. The results also showed a negative correlation between $\mathrm{CO}$ and $\mathrm{O}_{3}$, since carbon monoxide reacts with hydroxyl radicals producing $\mathrm{HO}_{2}$ radicals and, consequently, $\mathrm{NO}_{2}$ which is photo-dissociated to produce
$\mathrm{O}_{3}$.

It is also observed in Tables 1 and 2 that wind speed has a positive correlation with ozone concentration and a negative correlation with nitrogen oxides and carbon monoxide. This phenomenon may occur due to high wind speeds, which leads to the dispersion and mixing of the gases from local sources, favoring ozone transport and formation reactions taking place in the atmosphere [36]. Moreover, the positive correlation between wind speed and ozone levels can also be justified due to the transport of ozone produced on the main roads to the measurement 
Table 1 Spearman correlation coefficients between hourly mean $\mathrm{CO}, \mathrm{NO}, \mathrm{NO}_{2}, \mathrm{NO}_{x}, \mathrm{O}_{3}$ and meteorological parameters for winter nighttime and daytime

\begin{tabular}{|c|c|c|c|c|c|c|c|c|}
\hline \multicolumn{9}{|c|}{ Winter Daytime } \\
\hline & $\mathrm{CO}$ & $N O$ & $\mathrm{NO}_{2}$ & $\mathrm{O}_{3}$ & $T$. & R.H. & W.S. & S.R. \\
\hline $\mathrm{CO}$ & 1 & 0,780 & 0,693 & $-0,688$ & $-0,685$ & 0,629 & $-0,559$ & $-0,246$ \\
\hline NO & & 1 & 0,800 & $-0,622$ & $-0,543$ & 0,502 & $-0,410$ & $-0,154$ \\
\hline $\mathrm{NO}_{2}$ & & & 1 & $-0,356$ & $-0,281$ & 0,238 & $-0,380$ & $-0,251$ \\
\hline$O_{3}$ & & & & 1 & 0,852 & $-0,901$ & 0,715 & 0,518 \\
\hline$T$ & & & & & 1 & $-0,895$ & 0,586 & 0,485 \\
\hline R.H. & & & & & & 1 & $-0,554$ & $-0,543$ \\
\hline$W . S$. & & & & & & & 1 & 0,474 \\
\hline S.R. & & & & & & & & 1 \\
\hline \multicolumn{9}{|c|}{ Winter Nighttime } \\
\hline & $C O$ & $\mathrm{NO}$ & $\mathrm{NO}_{2}$ & $\mathrm{O}_{3}$ & $T$. & R.H. & W.S. & S.R. \\
\hline $\mathrm{CO}$ & 1 & 0,771 & 0,840 & $-0,791$ & $-0,568$ & 0,608 & $-0,358$ & 0,160 \\
\hline$N O$ & & 1 & 0,802 & $-0,672$ & $-0,391$ & 0,443 & $-0,346$ & 0,134 \\
\hline $\mathrm{NO}_{2}$ & & & 1 & $-0,518$ & $-0,283$ & 0,304 & $-0,300$ & 0,076 \\
\hline $\mathrm{O}_{3}$ & & & & 1 & 0,739 & $-0,860$ & 0,458 & $-0,295$ \\
\hline$T$ & & & & & 1 & $-0,702$ & 0,328 & $-0,177$ \\
\hline R.H. & & & & & & 1 & $-0,288$ & 0,392 \\
\hline W.S. & & & & & & & 1 & 0,088 \\
\hline$S . R$. & & & & & & & & 1 \\
\hline
\end{tabular}

T.-Temperature R.H.-Relative Humidity W.V.-Wind Speed S.R.-Solar Radiation

point [40]. There is also an expected negative correlation between ozone and relative humidity, since as relative humidity increases, the major photochemical paths of $\mathrm{O}_{3}$ removal will be lowered [41]. High humidity levels are associated with cloudy days and less sunshine, thus reducing photochemical processes [41].

\subsection{Local and regional contributions to ozone formation}

To determine the local and regional contribution to ozone formation, potential ozone levels $\left(\mathrm{O}_{3}+\mathrm{NO}_{2}\right)$, also called total oxidant levels $\left(O_{X}\right)$, were related to $N O_{X}$, following the same analysis used in other studies [42-44]. For this purpose, daily average values (day and night) of OX were evaluated against the values of $N O_{X}$. For each data distribution, a linear regression was applied, thus providing an equation in which the slope represents the local contribution ( $N O_{X}$-dependent), while the intersection represents the regional contribution ( $N O_{X}$-independent). Figure 4 presents the linear regressions lines obtained for each of the studied months. The regional contribution represents the background $O X$ concentration, while the local contribution is related to the local production/destruction [42].

When $O X$ levels increase as a function of $N O_{X}$, the $N O_{X}$ contributes mainly to ozone production; when the $O X$ levels decrease, it means that $N O_{X}$ influences the processes of ozone depletion; and when OX levels remain relatively constant as a function of $N O_{X}$, indicate that $N O_{X}$ contributes in equal parts to the production and depletion of ozone.

Based on the regression analysis from December 2018 to June 2019, it was possible to obtain the slope and intersection for each period. These results are presented in Figure 5, showing the monthly local and regional dependence of $O X$. It is noticeable that values of the local contribution are higher than the values of the regional contribution, thus indicating that for the industrial park of Mirandela $O X$ production occurs mainly locally due to primary pollutants emissions.

For the regional component, there is a tendency to an increase in the concentration of $O X$, because the intensification of solar radiation helps photochemical processes. This same tendency was observed in other studies [43]. Regarding the local component, for daytime, an increase in $O X$ concentration is observed from January to May, indicating that during this period, $N O_{X}$ favors ozone production. For the nighttime, the relationship is inverse, suggesting that that $N O_{X}$ is mainly related to ozone depletion mechanisms.

\subsection{Concentration-based critical level of ozone}

The accumulated AOT40 vegetation and forest levels were compiled in Figure 6 . It is noticed that the limits 
Table 2 Spearman correlation coefficients between hourly mean $\mathrm{CO}, \mathrm{NO}, \mathrm{NO}_{2}, \mathrm{NO}_{x}, \mathrm{O}_{3}$ and meteorological parameters for winter nighttime and daytime

\begin{tabular}{|c|c|c|c|c|c|c|c|c|}
\hline \multicolumn{9}{|c|}{ Spring Daytime } \\
\hline & $C O$ & $N O$ & $\mathrm{NO}_{2}$ & $\mathrm{O}_{3}$ & $T$. & R.H. & W.S. & S.R. \\
\hline $\mathrm{CO}$ & 1 & 0,675 & 0,781 & $-0,091$ & $-0,375$ & 0,330 & $-0,031$ & $-0,223$ \\
\hline$N O$ & & 1 & 0,906 & $-0,402$ & $-0,340$ & 0,369 & 0,001 & $-0,211$ \\
\hline $\mathrm{NO}_{2}$ & & & 1 & $-0,211$ & $-0,325$ & 0,296 & $-0,096$ & $-0,327$ \\
\hline $\mathrm{O}_{3}$ & & & & 1 & 0,531 & $-0,706$ & 0,313 & 0,328 \\
\hline$T$ & & & & & 1 & $-0,825$ & 0,159 & 0,498 \\
\hline R.H. & & & & & & 1 & $-0,175$ & $-0,528$ \\
\hline W.S. & & & & & & & 1 & 0,160 \\
\hline$S . R$. & & & & & & & & 1 \\
\hline \multicolumn{9}{|c|}{ Spring Nighttime } \\
\hline & $C O$ & $N O$ & $\mathrm{NO}_{2}$ & $\mathrm{O}_{3}$ & $T$. & R.H. & W.S. & S.R. \\
\hline $\mathrm{CO}$ & 1 & 0,142 & 0,458 & $-0,032$ & $-0,302$ & 0,164 & $-0,069$ & $-0,009$ \\
\hline$N O$ & & 1 & 0,684 & $-0,369$ & 0,071 & 0,178 & $-0,193$ & 0,403 \\
\hline $\mathrm{NO}_{2}$ & & & 1 & $-0,392$ & $-0,033$ & 0,113 & $-0,377$ & 0,200 \\
\hline $\mathrm{O}_{3}$ & & & & 1 & 0,450 & $-0,715$ & 0,702 & $-0,059$ \\
\hline$T$ & & & & & 1 & $-0,681$ & 0,345 & $-0,013$ \\
\hline R.H. & & & & & & 1 & $-0,482$ & 0,057 \\
\hline$W . V$. & & & & & & & 1 & 0,058 \\
\hline$S . R$. & & & & & & & & 1 \\
\hline
\end{tabular}

T.-Temperature R.H.-Relative Humidity W.V.-Wind Speed S.R.-Solar Radiation

for both AOT40 indexes were exceeded. For vegetation, the accumulated AOT exceeded $30 \%$ of the limit value, while for forests, the value exceeded $106 \%$ of the limit. It is noteworthy that these are the target values, but the long-term goal is to reduce the limit to $3000 \mathrm{ppb}$ for vegetation and 5000 for the forest.

For A0T60, the results are shown in Figure 7. The values of AOT60 were well below the limit of $2400 \mathrm{ppb}$, reaching at the end of September the value of $220 \mathrm{ppb}$. Considering that, April until September are the months with higher ozone formation, the value of AOT60 should not have high variations until the end of the year. This can also be seen in Figure 7 with the daily maximum 8-hour means, which show a downward trend with colder seasons. NET60 reached 38 days, exceeding in 13 days the limit of 25 days stipulated by the European Union. It is important to note that AOT40 and NET60 target values are averaged over 5 and 3 years respectively, thus, these values are a characterization of the current situation and may serve as a basis for the creation of reduction measures.

\subsection{Noise monitoring}

Figure 8 shows the hourly averages values during the spring months. Between Monday and Friday, the noise profile throughout the day is very similar, with the lowest averages observed between 1:00 and 3:00 at night. Subsequently, noise rises until 8:00, when activities start in the industrial zone, remaining relatively stable until 12:00. At that hour, there was a decrease in noise levels due to lunchtime, where most activities stop in the industrial zone. After 18h00, the noise level decreases due to the finish of the work hours. During the weekend, noise levels are lower than during working days, although Saturday levels are higher than those registered on Sundays because some activities operate on Saturdays.

Figure 9 presents the daily average night noise levels (Ln) and the day-evening-night-noise (Lden) levels during the spring days. The Portuguese Decree-Law No. 9/2007 of January 17 establishes for Lden a limit of $65 \mathrm{dBA}$ and for $\mathrm{Ln}$ a limit of $55 \mathrm{dBA}$ for mixed zones. During the evaluation time, the night indicator was exceeded on April $4^{\text {th }}, 15^{\text {th }}$, and $24^{t h}$, and May $8^{\text {th }}$ and $24^{\text {th }}$, reaching the values of $57.0,56.7,56.4,56.0$, and $55.6 \mathrm{dBA}$, respectively. As the exceeded values of $L n$ are very close to the established limit and occurred just a few times, it can be inferred that a singular event resulted in this phenomenon; therefore such values should be regarded as nonrelevant for the acoustic characterization of the industrial zone.

It should also be noted that although there are no legal limits for industrial parks, the observed values are within the legal limits for mixed zones, meaning that noise generated by activities in the industrial park of Mirandela, including traffic in roads, have little impact on the acoustic environment of the sensitive receivers located in its vicinity. During working days, noise remains relatively stable, close to $60 \mathrm{dBA}$, thus indicating that the noise sources in the industrial park have a typical behavior over 

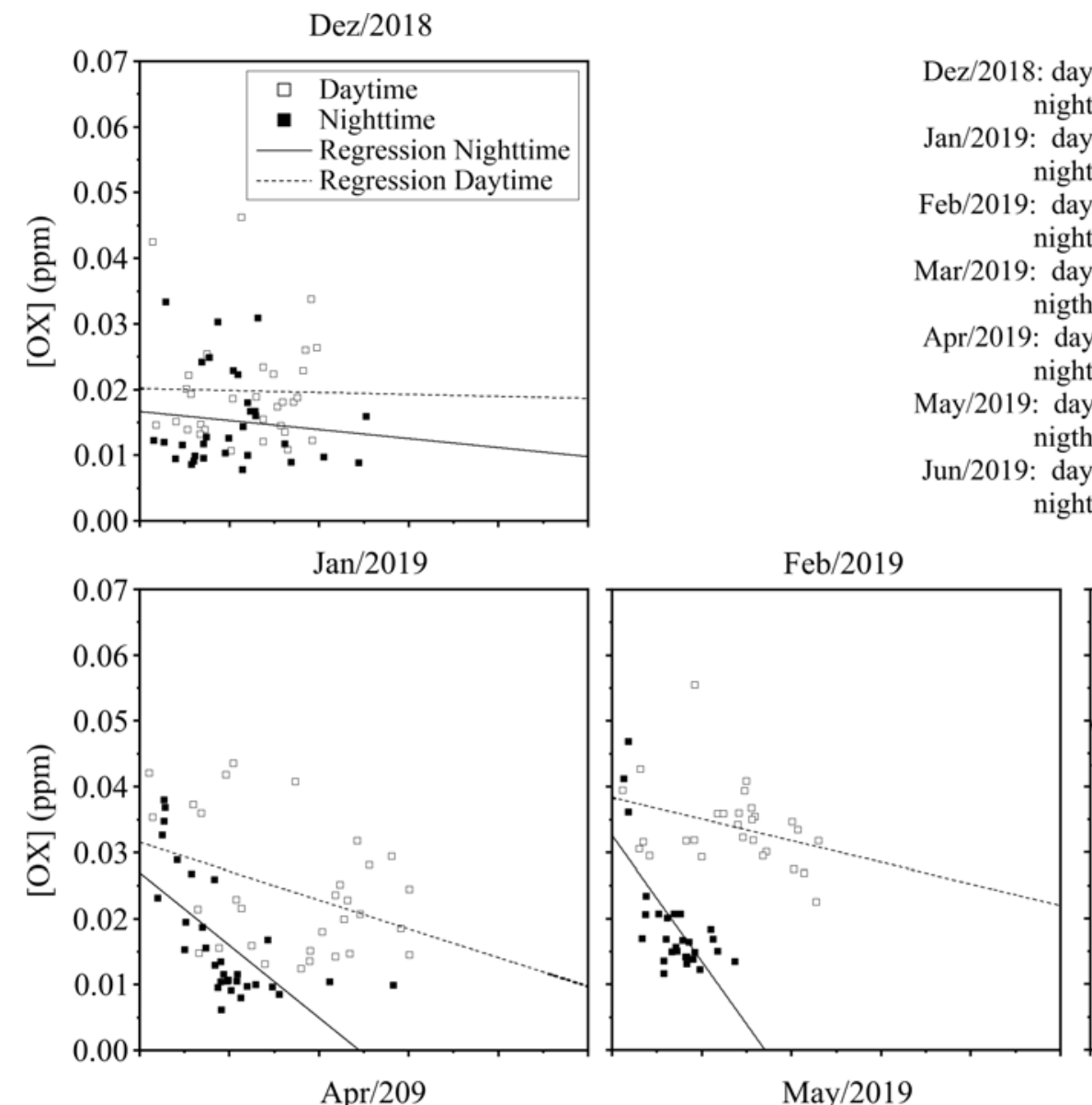

$\begin{aligned} \text { Dez/2018: daytime [OX] } & =0,02016-0,02991[\mathrm{NOX}] \\ \text { nighttime }[\mathrm{OX}] & =0,01665-0,13727[\mathrm{NOX}] \\ \text { Jan/2019: daytime }[\mathrm{OX}] & =0,03155-0,43667[\mathrm{NOX}]\end{aligned}$

nighttime $[\mathrm{OX}]=0,02697-1,10126[\mathrm{NOX}]$

$\mathrm{Feb} / 2019$ : daytime $[\mathrm{OX}]=0,03834-0,32714[\mathrm{NOX}]$ nighttime $[\mathrm{OX}]=0,03258-1,91055[\mathrm{NOX}]$

Mar/2019: daytime $[\mathrm{OX}]=0,04323-0,01416[\mathrm{NOX}]$ nigthtime $[\mathrm{OX}]=0,05058-5,61401[\mathrm{NOX}]$

Apr/2019: daytime $[\mathrm{OX}]=0,04596+0,52200[\mathrm{NOX}]$ nighttime $[\mathrm{OX}]=0,04815-4,45391[\mathrm{NOX}]$

May/2019: daytime $[\mathrm{OX}]=0,04611+0,45865[\mathrm{NOX}]$ nigthtime $[\mathrm{OX}]=0,04170-2,24625[\mathrm{NOX}]$

Jun/2019: daytime $[\mathrm{OX}]=0,05265-0,63883$ [NOX] nighttime $[\mathrm{OX}]=0,04318-2,79230[\mathrm{NOX}]$
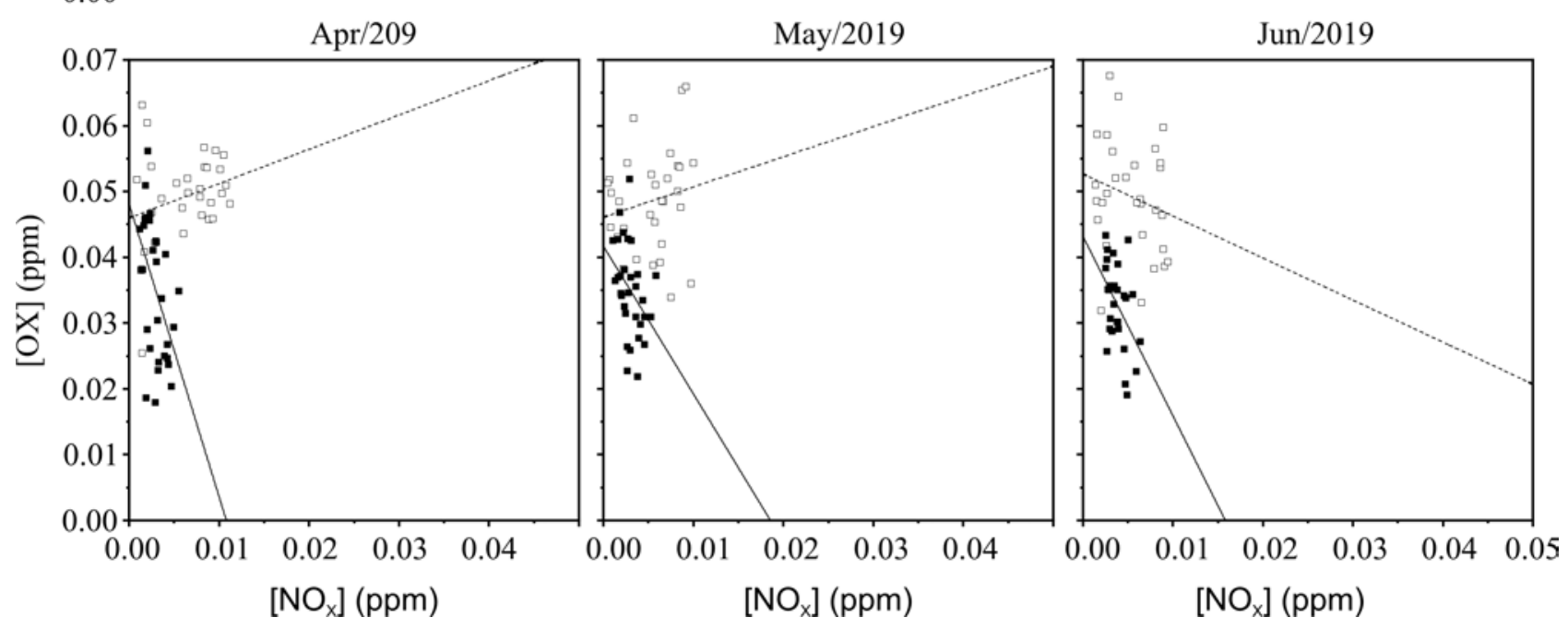

Figure 4 Daily variation means of regional $[O X]$ with $N O_{X}$ during the months of winter and spring for daytime and nighttime

the week.

It is noteworthy that only one fixed noise sensor was used in this study. Therefore, for a better acoustic characterization of the industrial zone, it would be necessary to install more noise sensors, considering that the sound is attenuated due to the obstacles and the distance traveled. Additional monitoring points would also add useful information on the diversity of noise sources.

\section{Noise and ozone control strategies}

For local ozone depletion, one of the simplest strategies is greening the industrial area. Trees absorb ozone efficiently and affect ozone production by increasing the dry deposition of $N O_{X}$, reducing the availability of this 


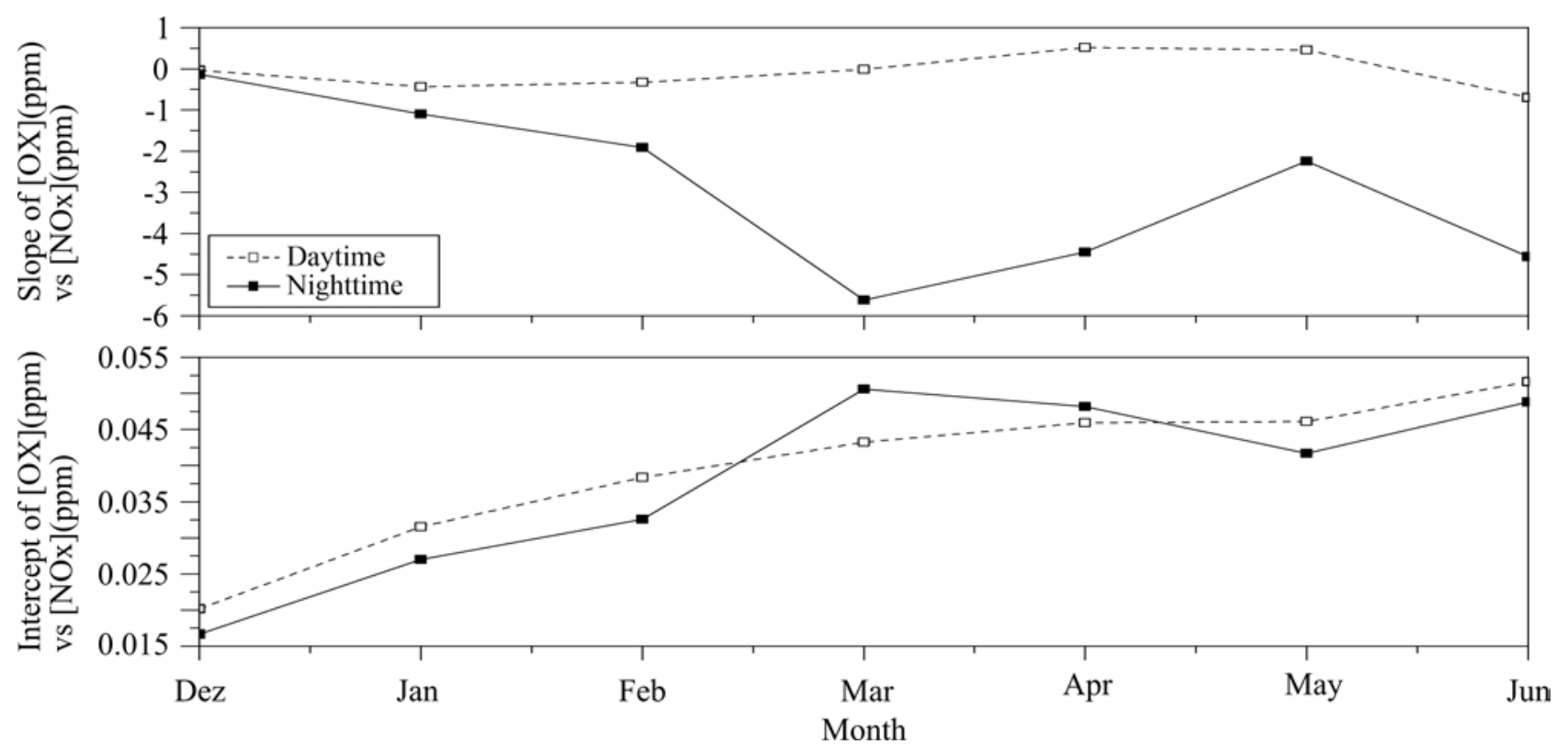

Figure 5 Monthly variation of regional (intercept) and local (slope) $O X$ in the Industrial Park of Mirandela

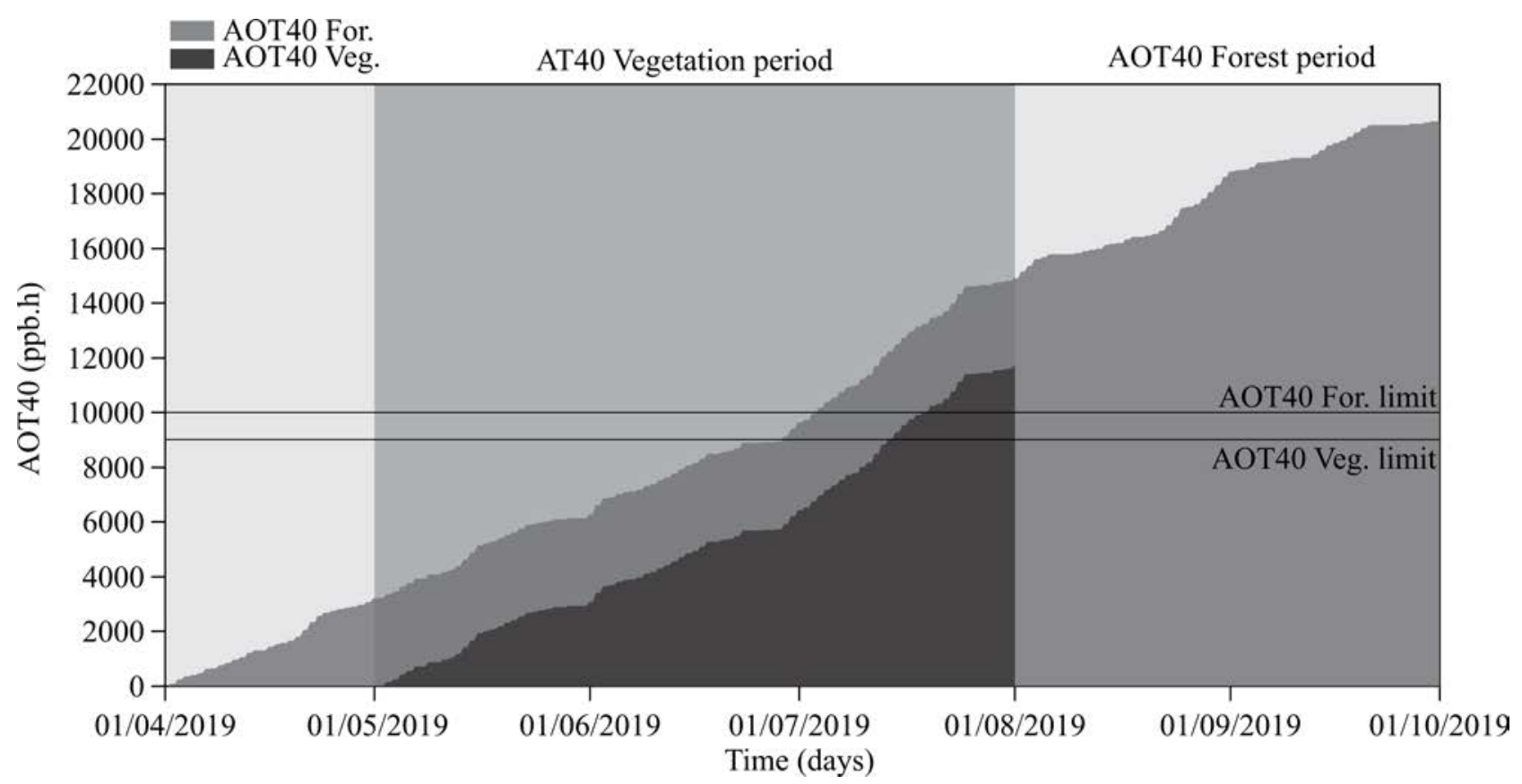

Figure 6 AOT40 forest and vegetation for the year 2019

pollutant in the atmosphere for ozone formation [45]. A study analyzing heat island reduction measures found that the increase in the vegetation cover and the use of reflective roofs and pavements can reduce local ozone production, mainly due to daytime temperature reduction [46].

Although high noise levels have not been found, setting up a tree belt at the industrial park boundaries would be a valuable combined measure to reduce ozone and noise levels in neighboring regions. Depending on the tree species and disposition, noise attenuation above $6 \mathrm{dBA}$ can be achieved, being more favorable the use of dense foliage and branches, which are more efficient in sound dispersion [47]. The use of vegetation also favors the absorption of noise by the soil, as it increases the porosity of the soil and consequently increases the surface absorption coefficient [48]. In addition, replacing dense-graded asphalt with a porous surface can achieve noise reduction values above 7 dBA [49]. 

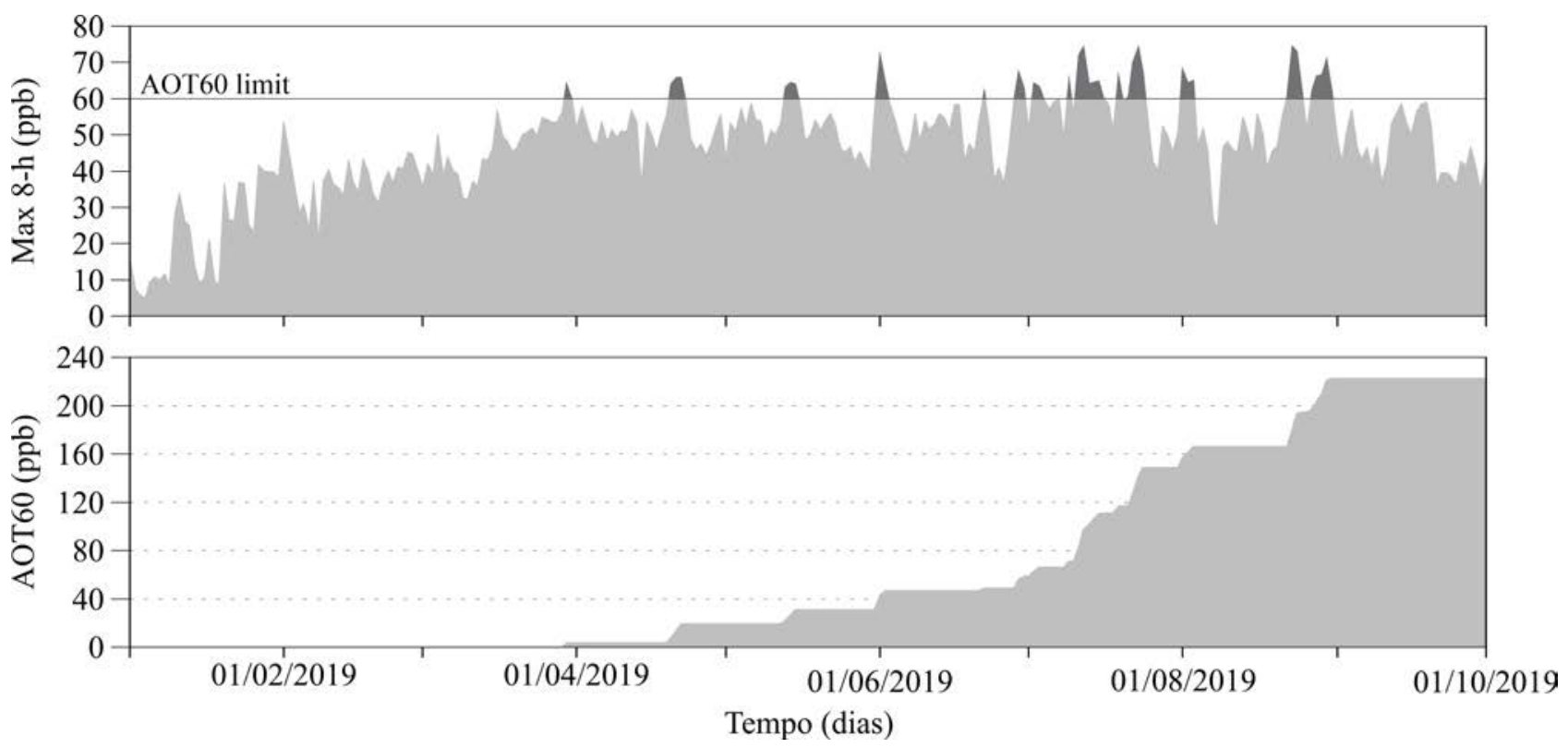

Figure 7 NET60 (top) and AOT60 (bottom) for the year 2019

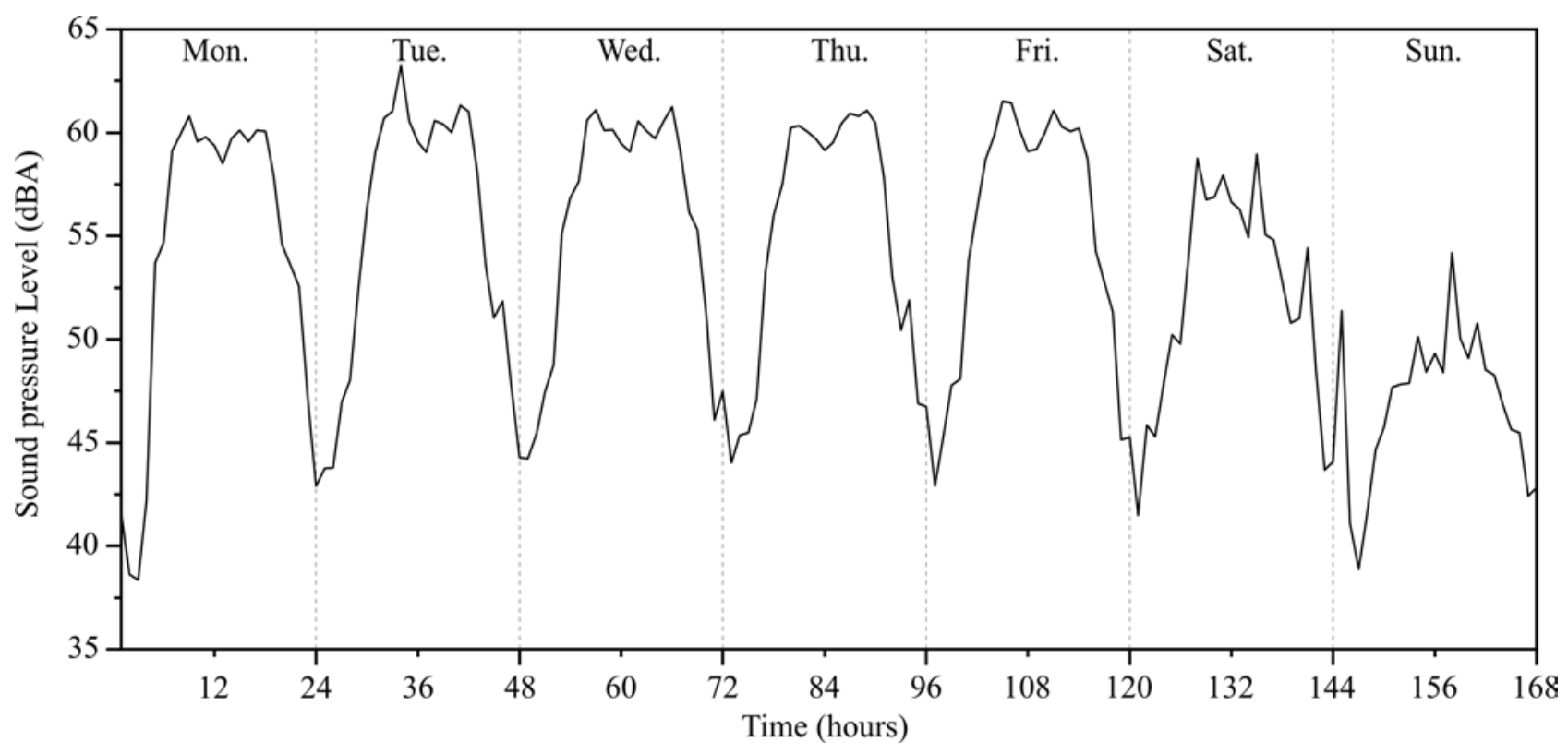

Figure 8 Average hourly variation of sound pressure levels for spring weeks

\section{Conclusions}

The monitoring of atmospheric pollution in the industrial park of Mirandela was useful for the identification of the main components related to the local ozone production, as it was possible to verify that besides the ozone precursors, the meteorological variables had a major influence on its production, and especially solar radiation. By analyzing the levels of AOT40 and NET60, it was found that the values are far above the long-term objectives, so it is indispensable to apply strategies that may reduce the concentration of ozone precursors.

$\mathrm{CO}$ and $\mathrm{NO}$ emissions were also related to urban traffic because their concentration increased at the same time during the rush hours in the industrial zone. Regarding the analysis of $O X$ vs $N O_{X}$, it was found that the ozone present in the region derives mainly from local influence, and the negative relationship found for the local component indicates that $N O_{X}$ favors ozone depletion mechanisms. Thus, in future studies, it is suggested to monitor $V O C s$ and hydrocarbons to better understand 


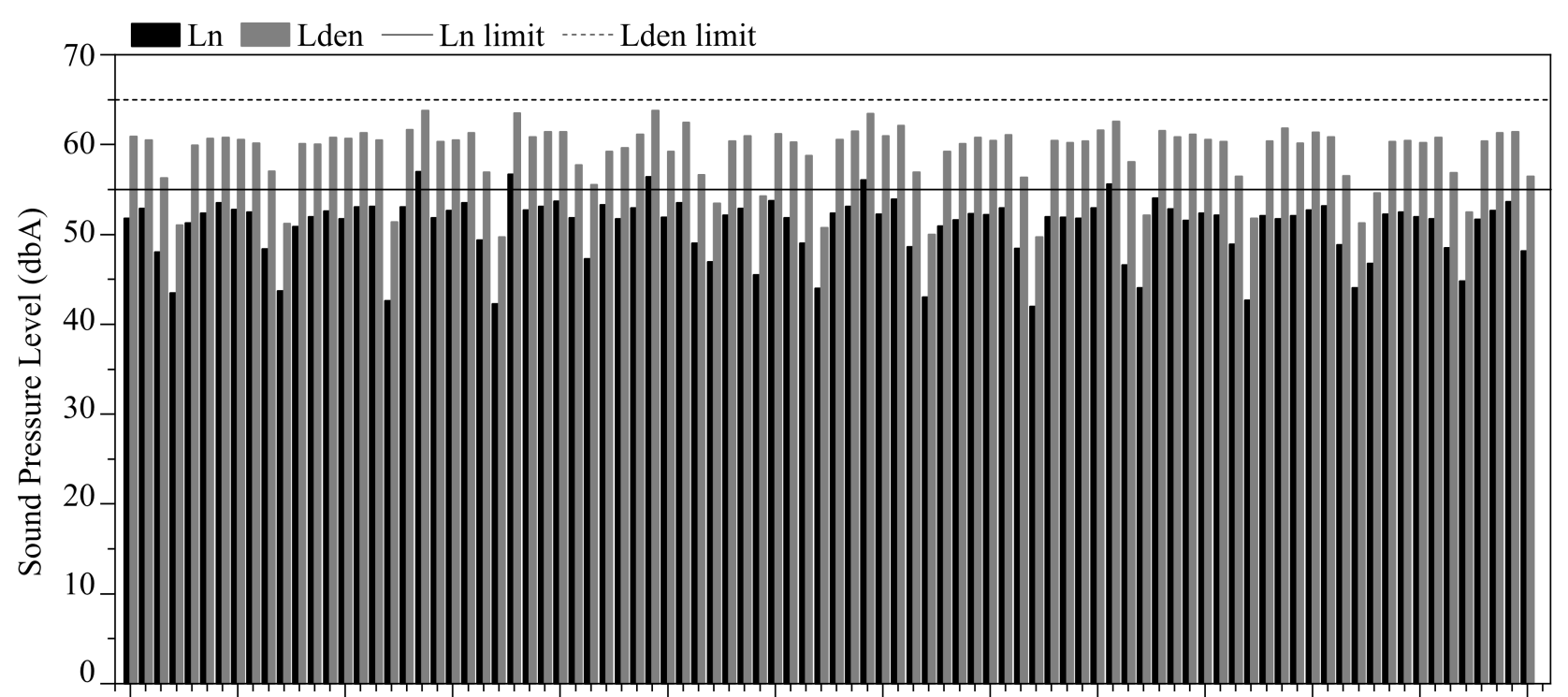

21 Mar 28 Mar 4 Apr 11 Apr 18 Apr 25 Apr 2 May 9 May 16 May 23 May 30 May 6 Jun 13 Jun 20 Jun

Time (days)

Figure 9 Ln and Lden levels for spring

the different ozone production routes and verify which pollutant has the highest impact on ozone synthesis.

By monitoring noise, it was possible to verify that during the observation period on five occasions, the night limit was exceeded; however, these values refer to the interior of the industrial park, and considering that these limits are for the receiving zones, the sound pressure levels most likely reach the sensitive zones around the industrial park at lower levels. Also, the daily and weekly noise profile showed a strong influence of local road traffic, with the highest values during the rush hours, between 8:00 and 9:00h, 17:00 and 18:00h.

\section{Declaration of competing interest}

We declare that we have no significant competing interests, including financial or non-financial, professional, or personal interests interfering with the full and objective presentation of the work described in this manuscript.

\section{Acknowledgements}

This study was part of the Trans-National Project Rehabind. The authors would like to thank the Spain-Portugal Transnational Program (POCTEP), with the Financial Support from the European Union under Program FEDER (European Regional Development Fund). The authors acknowledge all the support provided by the Mirandela City Council for the execution of this work. The authors thank the CYTED Thematic Network "CIUDADES
INTELIGENTES TOTALMENTE INTEGRALES, EFICIENTES Y SOSTENIBLES (CITIES)" no. 518RT0558.

\section{Funding}

This work was supported by the Spain-Portugal Transnational Program (POCTEP), with the Financial Support from the European Union under Program FEDER (European Regional Development Fund), as part of the project Rehabind (0399_REHAB_IND_2_E)

\section{Author contributions}

Conceptualization, L.F., M.F. and A.G.; Methodology, L.F., M.F. and F.R.; Validation, M.F. and A.G.; Formal Analysis, M.F. and A.G.; Investigation, L.F.; Data Curation, L.F. and M.F.; Original Draft Preparation, L.F.; Visualization, M.F. and A.G.; Supervision, M.F. and A.G; Project Administration, F.R.; Funding Acquisition, M.F., A.G and F.R.

\section{Data availability statement}

The data that support the findings of this study are available from the corresponding author upon reasonable request. 


\section{References}

[1] M. J. Molina and L. T. Molina, "Megacities and atmospheric pollution," Journal of the Air \& Waste Management Association, vol. 54, no. 6,2004

[2] W. Ren and et al., "Urbanization, land use, and water quality in Shanghai: 1947-1996," Environment International, vol. 29, Aug. 2003.

[3] M. Imperato and et al., "Spatial distribution of heavy metals in urban soils of Naples city (Italy)," Environmental Pollution, vol. 124, Jul. 2003.

[4] K. C. Seto, B. Güneralp, and L. R. Hutyra, “Global forecasts of urban expansion to 2030 and direct impacts on biodiversity and carbon pools," Proceedings of the National Academy of Sciences of the United States of America, vol. 109, Jul. 10, 2012.

[5] H. Romero, M. Ihl, A. Rivera, P. Zalazar, and P. Azocar, "Rapid urban growth, land-use changes and air pollution in Santiago, Chile," Atmospheric Environment, vol. 33, Oct. 1999.

[6] M. Semilof and et al., "Evaluación de la calidad del aire mediante un laboratorio móvil: Puente Aranda (Bogotá D.C., Colombia)," Revista Facultad de Ingenieria Universidad de Antioquia, no. 71, 2014.

[7] V.-A. H. Jadira, B.-M. K. Andrés, S.-G. O. Yazit, and G.-S. C. Eduardo, "Characterization of the urban heat island at bucaramanga, colombia, using real-time temperature monitoring," Revista Facultad de Ingeniería Universidad de Antioquia, no. 97, 2020.

[8] J. Morel, C. Marquis-Favre, S. Viollon, and M. Alayrac, "A laboratory study on total noise annoyance due to combined industrial noises," Acta Acustica united with Acustica, vol. 98, no. 2, 2012.

[9] 0. Hänninen and et al., "Environmental burden of disease in europe: Assessing nine risk factors in six countries," Environmental Health Perspectives, vol. 122, May. 1, 2014.

[10] C. Linares, J. Díaz, A. Tobías, J. M. D. Miguel, and A. Otero, “Impact of urban air pollutants and noise levels over daily hospital admissions in children in Madrid: a time series analysis," International Archives of Occupational and Environmental Health, vol. 79, Feb. 2006.

[11] A. Muzet, "Environmental noise, sleep and health," Sleep Medicine Reviews, vol. 11, Apr. 2007.

[12] M. Ji, D. S. Cohan, and M. L. Bell, "Meta-analysis of the association between short-term exposure to ambient ozone and respiratory hospital admissions," Environmental Research Letters, vol. 6, May. 3, 2011.

[13] W. Q. Gan, H. W. Davies, M. Koehoorn, and M. Brauer, "Association of long-term exposure to community noise and traffic-related air pollution with coronary heart disease mortality," American Journal of Epidemiology, vol. 175, Apr. 5, 2012.

[14] C. I. Falcón-Rodríguez, I. Rosas-Pérez, and P. Segura-Medina, "Relación de los mecanismos inmunológicos del asma y la contaminación ambiental," Revista de la Facultad de Medicina, vol. 65, Apr. 1, 2017.

[15] B. Jacquemin and et al., "Annoyance due to air pollution in europe," International Journal of Epidemiology, vol. 36, Aug. 2007.

[16] M. Basner and et al., "Auditory and non-auditory effects of noise on health," The Lancet, vol. 383, Apr. 2014.

[17] H. H. Eldien, "Noise mapping in urban environments: Application at suez city center." International Conference on Computers \& Industrial Engineering, 2019.

[18] D. J. Jacob, "Heterogeneous chemistry and tropospheric ozone," Atmospheric Environment, vol. 32, no. 12-14, 2000.

[19] J. H. Seinfeld and S. N. Pandis, Atmospheric Chemistry and Physics: From Air Pollution to Climate Change. Wiley, 3 ed., 2016.

[20] M. Z. Jacobson, Atmospheric Pollution. Cambridge University Press, 2016.

[21] European Parliament and the Council of the European Union, "Directive 2002/49/EC of the European Parliament and of the Council of 25 June 2002 relating to the assessment and management of environmental noise," Official Journal of the European Communities, vol. 189, Jul. 18, 2002.

[22] K. B. Schnelle, M. E. Ternes, and R. Dunn, Air Pollution Control Technology Handbook. CRC Press, 2 ed., 2017.

[23] C. Hohmann and et al., "Health effects of chronic noise exposure in pregnancy and childhood: A systematic review initiated by ENRIECO," International Journal of Hygiene and Environmental Health, vol. 216, Jun. 2013.

[24] G. C. M. Jr, "Noise," in Springer Handbook of Acoustics (T. D. Rossing, ed.), pp. 1001-1057, New York, NY: Springer, 2014.

[25] A. Leelőssy and et al., "Dispersion modeling of air pollutants in the atmosphere: a review," Central European Journal of Geosciences, vol. 6, Aug. 6, 2014.

[26] K. Attenborough, "Sound Propagation in the Atmosphere," in Springer Handbook of Acoustics (T. D. Rossing, ed.), pp. 117-155, New York, NY: Springer, 2014.

[27] C. N. Hewitt and A. V. Jackson, Atmospheric Science for Environmental Scientists. Chichester, Inglaterra: Wiley-Blackwell, 2009.

[28] J. M. Wallace and P. V. Hobbs, Atmospheric Science: An Introductory Survey. Elsevier, 2 ed., 2006.

[29] M. E. Jenkin and G. D. Hayman, "Photochemical ozone creation potentials for oxygenated volatile organic compounds: sensitivity to variations in kinetic and mechanistic parameters," Atmospheric Environment, vol. 33, Apr. 1999.

[30] European Parliament and Council of the European Union, “Directive 2008/50/EC of the European Parliament and of the Council of 21 May 2008 on ambient air quality and cleaner air for Europe," Official Journal of the European Union, May. 21, 2008.

[31] World Health Organization, Air quality guidelines for Europe. WHO Regional Publications, 2 ed., 2000.

[32] T. Spranger, U. Lorenz, and H.-D. Gregor, "Manual on methodologies and criteria for Modelling and Mapping Critical Loads \& Levels and Air Pollution Effects, Risks and Trends," Dec. 2004.

[33] Ad-Hoc Working Group, Ozone Position Paper. Luxembourg, 1999.

[34] European Parliament and the Council of the European Union, "Directive 2001/81/ec of the european parliament and of the council of 23 october 2001 on national emission ceilings for certain atmospheric pollutants," Official Journal of the European Communities, Nov. 27, 2001.

[35] Ministerio do Ambiente, do Ordenamento do Território e do Desenvolvimento Regional, “Decreto-lei n. 0 9/2007," Jan. 17, 2007.

[36] D. M. Agudelo-Castaneda, E. C. Teixeira, and F. N. Pereira, "Time-series analysis of surface ozone and nitrogen oxides concentrations in an urban area at Brazil," Atmospheric Pollution Research, vol. 5, Jul. 2014.

[37] M. D. la Guardia and S. Armenta, he Quality of Air. Amsterdam: Elsevier, 2016

[38] E. C. Teixeira, E. R. de Santana, F. Wiegand, and J. Fachel, "Measurement of surface ozone and its precursors in an urban area in South Brazil," Atmospheric Environment, vol. 43, Apr. 2009.

[39] D. Pudasainee and et al., "Ground level ozone concentrations and its association with $\mathrm{NO}_{\mathrm{x}}$ and meteorological parameters in Kathmandu valley, Nepal," Atmospheric Environment, vol. 40, Dec. 2006.

[40] D. M. Markovic and D. A. Markovic, "The relationship between some meteorological parameters and the tropospheric concentrations of ozone in the urban area of Belgrade," Journal of the Serbian Chemical Society, vol. 70, no. 12, 2005.

[41] T. Nishanth, M. K. S. Kumar, and K. T. Valsaraj, "Variations in surface ozone and $\mathrm{NO}_{\mathrm{x}}$ at Kannur: a tropical, coastal site in India," Journal of Atmospheric Chemistry, vol. 69, Jun. 5, 2012.

[42] M. E. Jenkin, "Analysis of sources and partitioning of oxidant in the UK-Part 2: contributions of nitrogen dioxide emissions and background ozone at a kerbside location in London," Atmospheric Environment, vol. 38, Sep. 2004.

[43] A. Notario and et al., "Analysis of $\mathrm{NO}, \mathrm{NO}_{2}, \mathrm{NO}_{x}, \mathrm{O}_{3}$ and oxidant l $\mathrm{OX}=$ $\mathrm{O}_{3}+\mathrm{NO}_{2}$ ) levels measured in a metropolitan area in the southwest of Iberian Peninsula," Atmospheric Research, vol. 104-105, Feb. 2012.

[44] L. J. Clapp and M. E. Jenkin, "Analysis of the relationship between ambient levels of $\mathrm{O}_{3}, \mathrm{NO}_{2}$ and $\mathrm{NO}$ as a function of $\mathrm{NO}_{\mathbf{x}}$ in the $\mathrm{UK}$," Atmospheric Environment, vol. 35, Dec. 2001.

[45] D. J. Nowak and et al., "A modeling study of the impact of urban trees on ozone," Atmospheric Environment, vol. 34, no. 10, 2000.

[46] H. Taha, S. Chang, and H. Akbari, "Meteorological and air quality impacts of heat island mitigation measures in three u.s. cities," Tech. Rep. LBNL-44222, Lawrence Berkeley National Laboratory, 
Berkeley, CA, Apr. 01, 2000.

[47] C. F. Fang and D.-L. Ling, "Investigation of the noise reduction provided by tree belts," Landscape and Urban Planning, vol. 63, May. 15, 2003.

[48] H. S. Yang, J. Kang, and C. Cheal, "Random-Incidence Absorption and Scattering Coefficients of Vegetation," Acta Acustica united with Acustica, vol. 99, May-Jun. 2013.

[49] P. R. Donavan, "Effect of Porous Pavement on Wayside Traffic Noise Levels," Transportation Research Record: Journal of the Transportation Research Board, vol. 2403, Jan. 1, 2014. 